\title{
Evaluation of the defensive behavior of two honeybee ecotypes using a laboratory test
}

\author{
Cecilia Andere ${ }^{1}$, M.A. Palacio ${ }^{2}$, E.M. Rodriguez ${ }^{1}$, E. Figini ${ }^{1}$, M.T. Dominguez ${ }^{1}$ and E. Bedascarrasbure ${ }^{1}$ \\ ${ }^{1}$ Facultad de Ciencias Veterinarias, Universidad Nacional del Centro de la Provincia de Buenos Aires. \\ ${ }^{2}$ Unidad Integrada INTA, Facultad de Ciencias Agrarias, Universidad Nacional de Mar del Plata, \\ Argentina. \\ ${ }^{3}$ E.E.A INTA Famaillá - Tucumán. Argentina.
}

\begin{abstract}
Honeybee defensive behavior is a useful selection criterion, especially in areas with Africanized honeybees (Apis mellifera $\mathrm{L}$ ). In all genetic improvement programs the selected characters must be measured with precision, and because of this we evaluated a metabolic method for testing honeybee defensive behavior in the laboratory for its usefulness in distinguishing between honeybee ecotypes and selecting honeybees based on their level of defensive responses. Ten honeybee colonies were used, five having been produced by feral queens from a subtropical region supposedly colonized by Africanized honeybees and five by queens from a temperate region apparently colonized by European honeybees. We evaluate honeybee defensive behavior using a metabolic test based on oxygen consumption after stimulation with an alarm pheromone, measuring the time to the first response, time to maximum oxygen consumption, duration of activity, oxygen consumption at first response, maximum oxygen consumption and total oxygen consumption, colonies being ranked according to the values obtained for each variable. Significant $(p<0.05)$ differences were detected between ecotypes for each variable but for all variables the highest rankings were obtained for colonies of subtropical origin, which had faster and more intense responses. All variables were highly associated $(p<0.05)$. Total oxygen consumption was the best indicator of metabolic activity for defensive behavior because it combined oxygen consumption and the length of the response. This laboratory method may be useful for evaluating the defensive behavior of honey bees in genetic programs designed to select less defensive bees.
\end{abstract}

Key words: honeybee, defensive behavior, oxygen consumption.

Received: June 21, 2000; accepted: March 14, 2002.

\section{Introduction}

Honeybee (Apis mellifera $\mathrm{L}$ ) defensive behavior is a complex trait that involves individual worker behavior and a coordinated colony response with a group effect. Although the biological mechanisms involved are well known, evaluation of this behavior is problematic because of the difficulty in quantifying this complex trait. Defensive behavior is one of the traits considered in selection programs in many areas of Argentina, especially where Africanized honeybees are present (Sheppard et al., 1991). In these honeybees (and other honeybee ecotypes that have not yet been characterized) a high level of defensive behavior makes colony management difficult. Many authors (Rothenbuhler, 1960; Stort, 1974; Collins et al, 1980, 1988;

Send correspondence to C. Andere. Facultad de Ciencias Veterinarias, Universidad Nacional del Centro de la Provincia de Buenos Aires, Paraje Arroyo Seco s/n. 7000 Tandil, Argentina. E-mail: candere@vet.unicen.edu.ar.
Moritz et al, 1985; Guzmán-Novoa and Page, 1993, 1994) have demonstrated genetic control of defensive behavior in honeybees and this parameter has been included in many genetic breeding programs, including the Integrated Project for Beekeeping Development (PROAPI) in Argentina.

In any genetic breeding program the characters to be selected must be quantified with precision, but this can only be done when there is an objective means of determining the traits to select. Many methods have been developed to measure honeybee defensive behavior, with some of them allowing estimation of traits in the field (Stort, 1974; Collins and Kubasek, 1982; Andere et al, 2000), such evaluations generally detecting differences in defensive behavior between ecotypes after several measurements (Andere et $a l, 2000)$. Other methods allow the measurement of defensive behavior under controlled experimental conditions in the laboratory (Collins and Rothenbuhler, 1978; Collins and Blum, 1982) and may be useful for selecting less 
defensive honeybees. Moritz et al, (1985) developed a metabolic test to quantify honeybee defensive behavior based on the measurement of oxygen consumption in honeybees after stimulation with an alarm pheromone, this test being independent of any environmental influence or observer subjectivity. In this paper we describe a method for testing the defensive behavior of bees in the laboratory to distinguish between ecotypes.

\section{Material and Methods}

Ten Apis mellifera L. colonies from different ecotypes were used. Five colonies (S1 to S5) originated from naturally mated feral queens from $26^{\circ} 4949 \mathrm{~S}, 65^{\circ} 12 \mathrm{~W}$ in Tucuman province, Argentina, this subtropical area being colonized by Africanized honey bees (Dietz et al., 1985; Dietz and Vergara, 1995; Sheppard et al., 1991), while the other five colonies (T1 to T5) were headed by naturally mated queens from $37^{\circ} 19 \mathrm{~S}, 59^{\circ} 0730 \mathrm{~W}$ in Tandil region, a temperate zone colonized by European honeybees, especially Apis mellifera ligustica (Dietz et al. 1985). At the start of the experiments, specimens of honeybees from each colony were sent to Hohenheim University in Germany to be characterized by morphometric analysis. Bees from $\mathrm{Tu}-$ cuman province differed from Africanized bees from Brazil and Uruguay and bees from Tandil differed from $A . m$. mellifera and A. m. ligustica from Europe (Andere et al, 2000), the colony ecotypes being classified as subtropical (S) for the Tucuman bees and temperate (T) for the Tandil bees. Colonies were installed in Langstroth hives and were standardized at the beginning to contain six brood combs, four honey combs and eight combs covered with bees.

Defensive behavior was evaluated as described by Moritz et al, (1985) with some modifications. A wire $10 \mathrm{~cm}$ $\mathrm{x} 15 \mathrm{~cm}$ screen was placed on a brood comb with emerging bees and $24 \mathrm{~h}$ later the bees which had emerged were painted on the thorax. After four days, the combs were removed from the colonies and the bees were anesthetized with $\mathrm{CO}_{2}$ and placed in a wire cell which was then put into the glass chamber described in the next paragraph. All the colonies were tested on the same day, with three evaluations (50 bees each) per colony. For each evaluation four-day old bees were placed in a $200 \mathrm{~mL}$ glass chamber contained in a water bath at $21^{\circ} \mathrm{C}$ and a continuous flow of fresh air $(20.8 \%(\mathrm{v} / \mathrm{v})$ oxygen), with or without the alarm pheromone isopentyl acetate (IPA), was pumped through the chamber at a rate of $200 \mathrm{~mL} /$ minute and into two gas washing containers, one with $\mathrm{CaCl}_{2}$ and the other with $\mathrm{NaOH}$. Oxygen level (indicating metabolic activity) and temperature were monitored with a digital oxygen meter using a polarographic probe. Each evaluation began when the oxygen level reached $20.8 \%$ (resting level) and ended when the initial level was regained, Figure 1 showing the changes in oxygen levels with time.

The variables analysed included time to the first response (T1R), time to maximum oxygen consumption

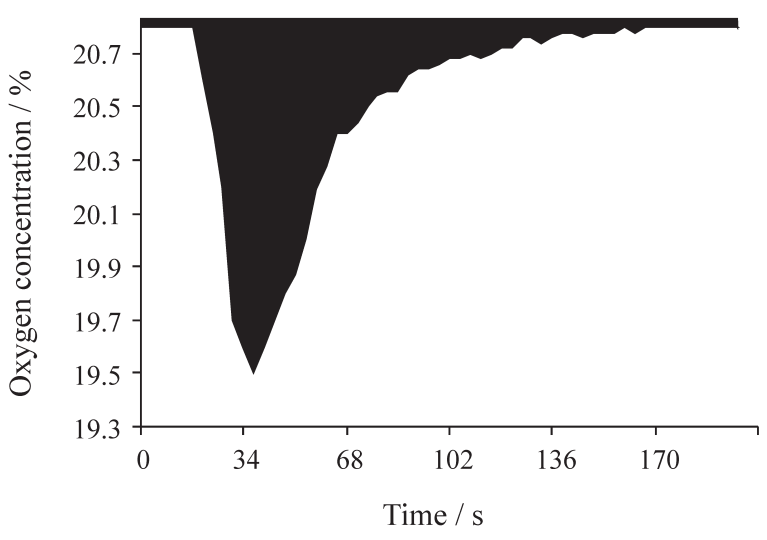

Figure 1 - Variation in $\mathrm{O}_{2}$ concentration with time.

(TMOC), duration time of activity (TAC), oxygen consumption during the first response (OC1R), maximum oxygen consumption (MOC) and total oxygen consumption (TOCA), colonies were being ranked from 1 to 10 according to the values obtained for each of the variables. Colonies with faster response times (T1R, TMOC), sustained activity levels (TAC) and higher values of oxygen consumption (OC1R, MOC and TOCA) were ranked higher in the scale. The data were analyzed using the SAS statistical package PROC GLM (SAS, 1989) and the Pearson correlation coefficient calculated to estimate the association between the variables measured.

\section{Results}

There were no significant differences for the measured variables between samples from the same colony and no interaction between ecotype and samples $(p>0.05)$. Then mean values and standard error for response time and oxygen consumption of both ecotypes are given in Table I and the rankings for response time and oxygen consumption of the different colonies in Table II.

There were significant differences between ecotypes for each variable $(p<0.05)$, temperate ecotype bees having slower and less intense responses. As shown by the fact that they reached the minimum oxygen level faster (33.4 s as against $51.4 \mathrm{~s}$ for temperate bees), bees from subtropical colonies were three times more active in terms of time of activity (TAC) than temperate bees and also had a two-fold greater oxygen consumption during the first response (OC1R) and a total oxygen consumption (TOCA) seven times greater than temperate bees. Subtropical bees ranked first for all variables, having faster reaction times (T1R, TMOC), more sustained activity (TAC) and higher oxygen consumption (OC1R, MOC and TOCA). The two ecotypes behaved differently when they received air containing IPA alarm pheromone as a stimulus, with subtropical bees showing more intense metabolic activity and higher oxygen consumption. 
Table I - Response time and oxygen consumption for subtropical and temperate honeybee colonies.

\begin{tabular}{|c|c|c|c|c|c|c|c|c|c|c|c|c|}
\hline \multirow[t]{2}{*}{$\begin{array}{l}\text { Honeybee } \\
\text { ecotype }\end{array}$} & \multicolumn{2}{|c|}{$\begin{array}{l}\text { Time to first } \\
\text { response } \\
\text { (T1R, s) }\end{array}$} & \multicolumn{2}{|c|}{$\begin{array}{l}\text { Time of } \\
\text { activity } \\
(\mathrm{TAC}, \mathrm{s})\end{array}$} & \multicolumn{2}{|c|}{$\begin{array}{l}\text { Time to maximum } \\
\mathrm{O}_{2} \text { consumption } \\
(\mathrm{TMOC}, \mathrm{s})\end{array}$} & \multicolumn{2}{|c|}{$\begin{array}{c}\mathrm{O}_{2} \text { consumption at } \\
\text { first response } \\
(\mathrm{OC} 1 \mathrm{R}, \%)\end{array}$} & \multicolumn{2}{|c|}{$\begin{array}{c}\text { Maximum } \mathrm{O}_{2} \\
\text { consumption } \\
(\mathrm{MOC}, \%)\end{array}$} & \multicolumn{2}{|c|}{$\begin{array}{c}\text { Total } \mathrm{O}_{2} \\
\text { consumption } \\
(\mathrm{TOCA}, \%)\end{array}$} \\
\hline & Mean & $\mathrm{SE}^{1}$ & Mean & SE & Mean & SE & Mean & $\mathrm{SE}$ & Mean & $\mathrm{SE}$ & Mean & SE \\
\hline Subtropical & 17.8 & 5.30 & 122.6 & 13.16 & 33.4 & 3.8 & 0.2 & 0.05 & 1.44 & 0.30 & 14.7 & 2.64 \\
\hline Temperate & 38.8 & 5.38 & 47.2 & 23.35 & 51.4 & 4.13 & 0.1 & 0.00 & 0.24 & 0.02 & 2.16 & 1.24 \\
\hline
\end{tabular}

${ }^{1} \mathrm{SE}=$ Standard error of the mean.

Table III shows that there was generally some association between the variables measured in this study, the strongest correlations being between MOC and TOCA $(\mathrm{r}=0.911, \mathrm{P}<0.01)$. Correlation between MOC and TAC was also significant $(\mathrm{r}=0.744, \mathrm{P}<0.01)$. Thus colonies with a greater oxygen consumption were active for a longer time and had a greater total oxygen consumption. The correlation between OC1R and the other variables also indicates that bees with high oxygen consumption in the first reaction were also active for a longer time and had high levels of total oxygen consumption.

\section{Discussion}

The results of this study agree with those of Moritz et al (1985) and indicate that it is possible to select less defensive honeybees based on their reaction to IPA alarm pheromone. In their study, Moritz et al (1985) were interested only in the difference between initial metabolic activity (resting levels) and maximum metabolic response (maximal activity, corresponding to MOC in our work) but in our study we measured other responses and found that both ecotypes also differed in their responses to these variables.

When MOC, measured after one minute (Southwick and Moritz, 1985), is the only parameter measured other

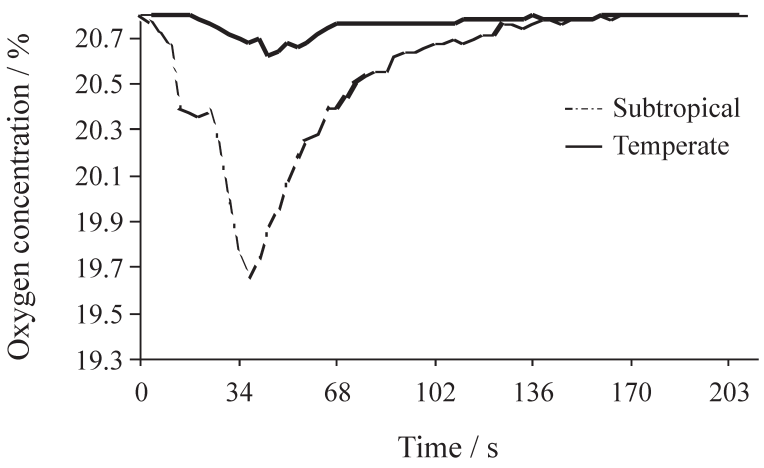

Figure 2 - Mean oxygen concentration in the air for both ecotypes following exposure to IPA.

important behavioral aspects are lost. We found that time of activity (TAC) was not by itself sufficient for classification since some colonies remained active for a long time but had low oxygen consumption. The only variable to combine oxygen consumption and the length of the response was total oxygen consumption (TOCA) which we found was probably the best estimate of metabolic activity during defensive behavior, this variable was also a good indicator with less aggressive bees. In our study, temperate bees reached maximum oxygen consumption (MOC) after one minute and it would have been difficult to detect differences in defensive

Table II - Ranking for response time and oxygen consumption for honeybee colonies from subtropical and temperate climates.

\begin{tabular}{|c|c|c|c|c|c|c|}
\hline Honeybee colony & $\begin{array}{l}\text { Time to first } \\
\text { response (T1R, s) }\end{array}$ & $\begin{array}{l}\text { Time of activity } \\
\quad(\mathrm{TAC}, \mathrm{s})\end{array}$ & $\begin{array}{c}\text { Time to maximum } \\
\mathrm{O}_{2} \text { consumption } \\
(\mathrm{TMOC}, \mathrm{s})\end{array}$ & $\begin{array}{c}\mathrm{O}_{2} \text { consumption at } \\
\text { first response } \\
(\mathrm{OC} 1 \mathrm{R}, \%)\end{array}$ & $\begin{array}{c}\text { Maximum } \mathrm{O}_{2} \\
\text { consumption } \\
(\mathrm{MOC}, \%)\end{array}$ & $\begin{array}{c}\text { Total } \mathrm{O}_{2} \\
\text { consumption } \\
\text { (TOCA, \%) }\end{array}$ \\
\hline & Rank & & & & & \\
\hline \multicolumn{7}{|l|}{ Subtropical } \\
\hline S1 & 3.5 & 5 & 2 & 2.5 & 5 & 5 \\
\hline S2 & 2 & 1 & 3.5 & 7 & 2 & 3 \\
\hline S3 & 5 & 6 & 3.5 & 7 & 4 & 4 \\
\hline S4 & 6 & 3 & 6 & 1 & 1 & 1 \\
\hline S5 & 1 & 4 & 1 & 2.5 & 3 & 2 \\
\hline \multicolumn{7}{|l|}{ Tropical } \\
\hline $\mathrm{T} 1$ & 3.5 & 7 & 8 & 7 & 6.5 & 7 \\
\hline $\mathrm{T} 2$ & 10 & 8 & 10 & 7 & 8 & 8 \\
\hline $\mathrm{T} 3$ & 9 & 10 & 7 & 7 & 8 & 10 \\
\hline $\mathrm{T} 4$ & 8 & 9 & 9 & 7 & 8 & 9 \\
\hline $\mathrm{T} 5$ & 7 & 2 & 5 & 7 & 6.5 & 6 \\
\hline
\end{tabular}


Table III - Correlation between the variables studied

\begin{tabular}{|c|c|c|c|c|c|c|c|c|c|c|}
\hline \multirow[t]{2}{*}{ Variable } & \multicolumn{2}{|c|}{$\begin{array}{c}\text { Total } \mathrm{O}_{2} \text { consumption } \\
(\mathrm{TOCA}, \%)\end{array}$} & \multicolumn{2}{|c|}{$\begin{array}{c}\text { Maximum } \mathrm{O}_{2} \text { consump- } \\
\text { tion }(\mathrm{MOC}, \%)\end{array}$} & \multicolumn{2}{|c|}{$\begin{array}{l}\mathrm{O}_{2} \text { consumption at first } \\
\text { response }(\mathrm{OC} 1 \mathrm{R}, \%)\end{array}$} & \multicolumn{2}{|c|}{$\begin{array}{c}\text { Time to maximum } \mathrm{O}_{2} \\
\text { consumption (TMOC, s) }\end{array}$} & \multicolumn{2}{|c|}{$\begin{array}{l}\text { Time of activity } \\
\text { (TAC, s) }\end{array}$} \\
\hline & $\mathrm{r}^{1}$ & $\mathrm{p}^{1}$ & $\mathrm{r}$ & $\mathrm{p}$ & $\mathrm{r}$ & $\mathrm{p}$ & $\mathrm{r}$ & $\mathrm{p}$ & r & $\mathrm{p}$ \\
\hline T1R & -0.396 & 0.0299 & -0.500 & 0.0048 & -0.147 & 0.4380 & 0.423 & 0.0198 & -0.615 & 0.0003 \\
\hline TAC & 0.769 & 0.0001 & 0.744 & 0.0001 & 0.539 & 0.0021 & -0.186 & 0.3247 & & \\
\hline TMOC & -0.355 & 0.0536 & -0.414 & 0.0228 & -0.311 & 0.0938 & & & & \\
\hline OC1R & 0.838 & 0.0001 & 0.734 & 0.0001 & & & & & & \\
\hline MOC & 0.911 & 0.0001 & & & & & & & & \\
\hline
\end{tabular}

${ }^{1}$ Correlation coefficient.

${ }^{2}$ Probability level.

behavior if $\mathrm{MOC}$ or the time to maximum oxygen consumption (TMOC) were the only indicators.

Southwick and Moritz (1985) stated that temperature, pheromone dose and the number of bees should be kept constant during all evaluations, although the bees can be allowed to respond to changes in pheromone levels (Southwick and Moritz, 1985; Moritz and Southwick, 1987). The influence of age of honeybee on their metabolic response has been studied by Collins and Rothembuhler (1978), Collins (1980) and Andere et al (2000) and it has been found that four-day old bees are better at discriminating between colonies than older bees. In addition older bees produce greater amounts of IPA alarm pheromone which could cause secondary reactions in other bees during testing (Moritz et al, 1985).

Our study has shown that it is possible to discriminate between temperate and subtropical honeybees based on their defensive behavior in the laboratory. However, this approach is not sufficient to conclusively discriminate between ecotypes and other techniques such as morphometric and DNA analysis are required. However, the method described here may be useful for selecting less defensive honeybees in breeding programs.

\section{Acknowledgments}

The authors thank Dr. Peter Rosenkranz for the characterizing the ecotypes and Dr. Anita Collins, Dr. Alfred Dietz and Dr. Michael Breed for helpful discussions during the experiments.

\section{References}

Andere C, Palacio MA, Rodriguez E, Dominguez MT, Figini E and Bedascarrasbure E (2000) Evaluation of honeybees defensive behavior in Argentina. I. A field method. American Bee Journal 140 (12):975-978.

Collins AM (1980) Effect of age on the response to alarm pheromones by caged honey bees. Ann. Entom. Soc. Am. 73:307-309.

Collins AM and Blum MS (1982) Bioassay of compounds derived from the honey bee sting. J. Chem. Ecol. 8:463-470.
Collins AM and Kubasek KJ (1982) Field test of honey bee (Hym. Apidae) colony defensive behavior. Ann. Entom. Soc. Am. 75:383-387.

Collins AM, Rinderer T and Tucker K (1988) Colony defense of two honeybee types and their hybrid. 1 Naturally mated queens. J. Apic. Res. 27:137-140.

Collins AM, Rinderer T, Tucker K, Sylvester A and Lackett J (1980). A model of honeybee defensive behaviour. J. Apic. Res. 19:224-231.

Collins AM and Rothenbuhler WC (1978) Laboratory test of the response to an alarm chemical, isopentyl acetate, by Apis mellifera. Ann. Entom. Soc. Am 71:906-909.

Dietz A, Krell R and Eischen FA (1985) Preliminary investigation on the distribution of Africanized honey bees in Argentina. Apidologie 16:99-107.

Dietz A and Vergara C (1995) Africanized honey bees in temperate zones. Bee World 76:56-71.

Guzmán-Novoa E and Page RE (1993) Backrossing Africanized honey bee queens to European drones reduces colony defensive behavior. Ann. Entomol. Soc. Am. 86:352-355.

Guzmán-Novoa E and Page RE (1994) Genetic dominance and worker interactions affect honeybee colony defense. Behav. Ecol. 5:91-97.

Moritz RF and Southwick EE (1987).Phenotype interactions in group behaviour of honey bee workers (Apis mellifera L.). Behav. Ecol. Sociobiol. 21:53-57.

Moritz RF, Southwick EE and Breh M (1985) A metabolic test for the quantitative analysis of alarm behavior of honeybees (Apis mellifera L.). J. Exp. Zool. 235:1-5.

Rothenbuhler WC (1960) A technique for studying genetics of colony behavior in honey bees. Am. Bee J. 100:176-198.

SAS Institute Inc. (1989) SAS/STAT User's Guide, Version 6, Fourth Edition, V SAS v. 2, Cary, NC: SAS Institute Inc. $943 \mathrm{pp}$.

Sheppard WS, Rinderer TE, Mazzoli JA, Stelzer AJ and Shimanuki H (1991) Gene flow between African-and European-derived honey bee populations in Argentina. Nature. 349:782-784.

Southwick EE and Moritz RFA (1985) Metabolic response to alarm pheromone in honey bees. J. Insect Physiol. 31:389-392.

Stort AC (1974) Genetic study of aggressiveness of two subspecies of Apis mellifera in Brazil. I Some tests to measure aggressiveness. J. Apic. Res. 13:33-38. 